\title{
FOREIGN AID ON ECONOMIC GROWTH IN AFRICA: A COMPARISON OF LOW AND MIDDLE-INCOME COUNTRIES
}

\author{
Aye Mengistu Alemu* \\ SolBridge International School of Business, South Korea \\ Jin-Sang Lee \\ Duksung Women's University, Seoul, South Korea
}

\begin{abstract}
Previous empirical studies on the effects of foreign aid on economic growth have generated mixed results that make it difficult to draw policy recommendations. The main reason for such mixed results is the choice of a single aggregate list of countries, regardless of the disparities in levels of development. This study therefore fills the development gap by disaggregating the African data into a panel of 20 middle- income and 19 low- income African countries over a period of 15 years between 1995 and 2010, and employing a dynamic generalized method of moments (GMM) model to address the dynamic nature of economic growth as well as the problems of endogeneity. The results of this study support the theoretical hypothesis that a positive relationship between aid and GDP growth exists, but only for low-income African countries, not middle-income ones. On the other hand, the study reveals that middle- income African countries tend to experience a greater impact on their economic growth from foreign direct investment (FDI) and natural resources revenues, mainly oil exports. This implies that the frequent criticism that foreign aid has not contributed to economic growth is flawed, at least in the case of low-income African countries. In fact, foreign aid has played a critical role in stimulating economic growth in such countries through supplementing domestic sources of finance such as savings, thus increasing the amount of investment and capital stock in them.
\end{abstract}

Key words: foreign aid, FDI, economic growth, Africa, disaggregated data, GMM model

JEL: F5, 23, O4, 55, C8, 4

\section{$1 \quad$ Introduction}

The role of foreign aid in the growth process of developing countries has been a topic of intense debate. It is estimated that Africa has received more than one trillion US dollars during the last 50 years (Moyo, 2009). However, many countries are still under-developed and depend on foreign aid to run themselves, indicating that this aid has not been effective.

The issue of aid effectiveness was brought vigorously to the fore in 2005 when the Paris Declaration (PD) was endorsed by organization for Economic Co-operation and Development (OECD) Development Assistance Committee (DAC) members. Despite continuous aid to African countries, some of them became worse off than they were in the early 1960s. From a recipient country's point of view, aid should be short-term, when the country suffers a shock internally or externally. Likewise, many low- income countries in Africa do not have great opportunities for FDI since they receive limited attention from multinational companies (MNCs). In such cases, most low-income African countries mainly tend to have foreign aid, at least to provide their population with basic services such as education, health, roads, etc., and possibly to build institutional capacity to govern their countries. Foreign aid to low-income countries may also flow in in various forms such as cash, projects, programs, education and training, technical assistance and others.

Middle- income countries in Africa have a substantial quantity of natural resources that are economical and act as a "pulling" factor for FDI. However, the majority of low-income African countries have very low levels of economic infrastructure such as transportation and basic services 
as well as low levels of human capacity in terms of elementary and secondary enrollment ratios as well as vocational and technical training opportunities. These economic and social environments make it difficult for low-income African countries to achieve economic development. Consequently, most of the low-income African countries are heavily dependent upon foreign aid which is mostly channeled through humanitarian aid such as food and emergency needs, with only a small portion being utilized for economic infrastructure.

However, empirical studies on foreign aid and economic growth in developing countries have generated mixed results that make it difficult to draw policy recommendations. The main objective of this study is therefore to investigate the effects of foreign aid on economic growth in low-income and non-low-income African countries.

\section{Literature review}

Theoretically, the main role of foreign aid in stimulating economic growth is to supplement domestic sources of finance such as savings, thus increasing the amount of investment and capital stock. As Morrissey (2001) points out, there are a number of mechanisms through which aid can contribute to economic growth, including: (a) increased investment, in physical and human capital; (b) increased capacity to import capital goods or technology; (c) lack of indirect effects that reduce investment or savings rates; and (d) transfer of technology that increases the productivity of capital and promotes endogenous technical change.

There are four strands of literature on the role of foreign aid on economic growth. The first studies claim that foreign capital inflow is necessary and sufficient for economic growth in lessdeveloped countries. They assert that there is a positive relationship between aid and economic growth because it not only augments domestic resources, but also supplements domestic savings, assists in closing the foreign exchange gap, creates access to modern technology and managerial skills, and allows easier access to foreign markets, ultimately leading to economic growth (Chenery \& Strout, 1996; Islam, 1992; Dalgaard, Hansen \& Tarp, 2004; Gupta \& Islam, 1983; Burnside \& Dollar, 2000; Hansen \& Tarp, 2000; Morrissey, 2001; Gomanee et al., 2005). By the same token, Pallage and Robe (2001) noted that foreign aid is a major source of economic growth for developing countries, especially in Africa, where it averages 12.5 per cent of the gross domestic product and establishes by far the most important source of foreign capital. Under such circumstances, foreign aid has the potential to play a key role in boosting developing countries' economic growth as well as reducing poverty. Similarly, Addison, Mavrotas and McGillivray (2005) examined the trends of ODA to Africa over the period 1960 to 2002, and concluded that foreign aid does in fact promote growth and reduce poverty. It also has a positive impact on the public sector, contributing to higher public spending and lower domestic borrowing. Burnside and Dollar (2000) also examined the effect of aid on economic growth, using standard cross-country panel regressions that included an interaction term of aid with a policy index and found that aid has a positive impact on growth in developing countries as long as these countries have sound macroeconomic policies.

The second group of studies assert that external capital has significant negative effects on the economic growth of recipient countries. According to this view, foreign aid is fully consumed; it substitutes rather than complements domestic resources; assists import of inappropriate technology; distorts domestic income distribution; and encourages a bigger bloated?, inefficient and corrupt government in developing countries (Boone, 1996; Easterly, 2003).

The third view is that foreign aid has no impact on economic growth (Mosley, 1980; Mosley et al., 1987). This view is shared by Moyo (2009) who argues that aid has not helped to improve social and economic conditions in Africa for several reasons: a) sectors that are critical and important to the development of the country have rarely been allocated any resources and less than 6.5 per cent of development aid or assistance received by developing countries over the years has been allocated to areas that are critical to accelerated growth and economic development, such as education, healthcare, infrastructure, energy, agriculture, technology, and the environment; b) the 
debt and aid resources have been stolen and corruptly squandered by government officials to enrich themselves, their families, and friends instead of being directed to the productive sectors of the national economy; c) during the cold war, the policies of the developed countries favoured African countries that were friendly with them and as a result, Official Development Aid (ODA) was usually quite unpredictable and could not be depended on for making long-term development plans. In addition, many of the Western donors often attached conditions to aid that made its effective use for development difficult; d) in many instances, aid was driven by interest groups in the developed countries to sell their products, services, and technologies that were not suitable for African development because they were often obsolete and inappropriate for African conditions.

The fourth view is that the relationship between foreign aid and economic growth may depend on the quality of the recipient country's institutions and economic policies, i.e., integrated monetary, fiscal, and trade policies (Burnside \& Dollar, 2000; McGillivray et al., 2006). McGillivray et al. (2006) suggested four different views from positive and negative perspectives and emphasized political conditions and institutional capacity. According to Mbaku (2004), African countries failed to use aid efficiently because they lacked competent laws and institutions to use received aid appropriately and effectively. Kosack (2003) examined the impact on the human development index, only in democratic countries. He found that aid has a negative impact in autocratic countries but a positive impact on the human development index and growth in democratic ones.

However, it must be borne in mind that regional differences in the effects of foreign aid among the recipient countries are inevitable. Effects could be influenced by income levels or levels of socio-economic development of recipient countries. Ekanayake and Charrna (2010) analyzed 83 recipient countries in Asia, Africa and Latin America and the Caribbean, using panel data series for foreign aid, and concluded that foreign aid brought mixed impacts on the economic growth of recipient countries. Latin American and the Caribbean countries especially experienced adverse effects on economic growth, while African countries showed positive effects. Ree and Nillesen (2009) studied the impact of foreign aid on civil conflict in sub-Saharan Africa but found no evidence that foreign aid has impact on civil conflicts. Some studies show different evidence: negative effects in the short term but positive ones in the long run. For example, Moreira (2005) carried out a study of the impact of economic growth at the macro-level using a cross-country regression model and examined the short- and the long term results. The long term effects were found to be better than those in the short term. Juselius, Framroze and Tarp (2011) also found that the impact of foreign aid was positive in the long run.

\section{Methodology}

\subsection{Scope of the study}

Though often spoken of as a single, homogenous group, African countries are remarkably diverse and heterogeneous in historical, political, social, economic, linguistic, cultural and geographical terms. The region includes both middle-income, lower middle- income, upper middle- income and higher- income economies, some with large and some with small populations; some with a store of natural resources and those with virtually none. Thus it is important to examine in detail whether the effect of foreign aid on economic growth in Africa has been uniform. Accordingly, African countries have been categorised into low-income and non-low- income countries based on the World Bank's classification (low-income: Gross National Income (GNI) per capita $\leq \$ 1,005$; lower-middle income economies: $\$ 1,006 \leq$ GNI per capita $\leq \$ 3$, 975; upper-middle income African economies: $\$ 3,976 \leq$ GNI per capita $\leq \$ 12,275$; and higher-income economies: GNI per capita $\geq 12,276$ ). 
Table 1

List of countries included in the study

\begin{tabular}{|l|l|}
\hline \multicolumn{1}{|c|}{ Low-income Africa (20 countries) } & \multicolumn{1}{c|}{ Non-low- income Africa (19 countries) } \\
\hline Benin, Burkina-Faso, Burundi, Chad, & Higher- income economies \\
Democratic Republic of Congo, Ethiopia, & Equatorial Guinea \\
Gambia, Guinea Bissau, Kenya, Malawi, & Upper- middle economies \\
Madagascar, Mali, Mauritania, & Algeria, Libya, Botswana, Gabon, Mauritius, Seychelles, South Africa and Tunisia \\
Mozambique, Rwanda, Sierra Leone, & Lower-middle economies \\
Tanzania, Togo and Uganda. & Angola, Congo Republic, Cote d'lvoire, Cape Verde, Egypt, Ghana, Morocco, \\
& Namibia, Nigeria, Senegal, Zambia. \\
\hline
\end{tabular}

\subsection{Specifications of model}

This section discusses the model specifications to examine the relationships between foreign aid and economic growth. The empirical model for estimating the impact of foreign aid on economic growth is based on previous growth literature and other empirical studies. Therefore, in deriving our empirical model for estimating the aid-growth relationship, we posit that:

$$
\Delta \mathrm{Y}_{\mathrm{it}}=\mathrm{f}\left(\mathrm{PC}_{\mathrm{it}}, \mathrm{HC}_{\mathrm{it}}, \mathrm{NR}_{\mathrm{it}}, \mathrm{Z}_{\mathrm{it}}\right)
$$

Where $\Delta \mathrm{Y}_{\text {it }}$ denotes economic growth in real per capita GDP of country $i$ at time $t, \mathrm{PC}_{\mathrm{it}}$ is a vector of physical capital sources of country $i$ at time $t, \mathrm{HC}_{i t}$ is a vector of human capital of country $i$ at time $t, N_{i t}$ is a vector of natural resources of country $i$ at time $t$, and $Z_{i t}$ is a vector of other growth-determining policy and institutional variables as explained in the empirical literature. The endogenous growth model in particular emphasizes the importance of capital (both physical and human), as well as policy and institutional factors in promoting economic growth. On this basis, our model can be specified as follows:

$$
\Delta \mathrm{Y}_{\mathrm{it}}=\alpha+\beta \mathrm{PC}_{\mathrm{it}}+\eta \mathrm{HC}_{\mathrm{it}}+\delta \mathrm{NR}_{\mathrm{it}}+\gamma \mathrm{Z}_{\mathrm{it}}+\mu_{\mathrm{t}}
$$

Where $\Delta \mathrm{Y}_{\text {it }}$ is economic growth in real per capita, $\mathrm{PC}_{\mathrm{it},} \mathrm{HC}_{\mathrm{it}}, \mathrm{NR}_{\mathrm{it}}$ and $\mathrm{Z}_{\mathrm{it}}$ are already mentioned above, $\mu_{\mathrm{t}}$ is the error term.

On the other hand, critical capital sources for economic growth of developing countries comprise foreign aid, domestic investment (DI) and foreign direct investment (FDI).

Hence, $\mathrm{PC}=\mathrm{f}($ Aid, DI, FDI)

Where 'Aid' denotes foreign aid, which is net official development assistance (ODA) as a share of GDP, DI denotes domestic investment which is gross capital formation (GCF) as a share of GDP, and FDI represents the share of foreign direct investment to GDP.

Similarly, we can break human capital (HC) down into two components: education, which is captured by enrolment ratio; and health, which is estimated by life expectancy.

Hence, $\mathrm{HC}=\mathrm{f}$ (education, health)

Natural resources $(\mathrm{NR})=\mathrm{f}$ (oil exports, ores and metals exports, arable land ratio)

$\mathrm{Z}=\mathrm{f}($ Policy, Institutional $)=\mathrm{f}($ degree of openness, exchange rate, inflation

index, economic freedom, quality of infrastructure)

Thus, substituting (3), (4), (5) and (6) in (2), produces our refined model as:

$$
\begin{aligned}
& \Delta \mathrm{Y}_{\mathrm{it}}=\alpha+\beta_{1} \mathrm{Aid}_{\mathrm{it}}+\beta_{2} \mathrm{DI}_{\mathrm{it}}+\beta_{3} \mathrm{FDI}_{\mathrm{it}}+\beta_{4} \mathrm{SER}_{\mathrm{it}}+\beta_{5} \mathrm{LXP}_{\mathrm{it}}+\beta_{6} \mathrm{OIL}_{\mathrm{it}}+\beta_{7} \mathrm{ORE}_{\mathrm{it}}+\beta_{8} \\
& \mathrm{OPEN}_{\mathrm{it}}+\beta_{9} \mathrm{EXCH}_{\mathrm{it}}+\beta_{10} \mathrm{INF}_{\mathrm{it}}+\beta_{11} \mathrm{EFRD}_{\mathrm{it}}+\beta_{12} \mathrm{INFR}_{\mathrm{it}}+\beta_{13} \mathrm{LOCK}_{\mathrm{it}}+\mu_{\mathrm{t}}
\end{aligned}
$$

\subsection{Choice of explanatory variables}

\subsubsection{Foreign aid}

The relationship between foreign aid and economic growth is not conclusive, and this has already been discussed in detail in Section 3 of this article. The traditional justification for foreign aid is that it eases the resource constraints of developing economies, especially on the supply side (Munemo et al., 2007). In this view, therefore, foreign aid is regarded as a positive coefficient on economic growth. 


\subsubsection{FDI inflow}

The neoclassical approach assumes that FDI promotes economic growth by introducing valuable capital and technology into recipient countries. Moreover, FDI is one of the main avenues for the movement of technology, management know-how and modern business methods across national borders. Therefore, the rationale for increased efforts to attract more FDI stems from the belief that FDI has several positive impacts on economic growth through productivity gains, technology transfers, the introduction of new processes, managerial skills, know-how in the domestic market, employee training, international production networks, and access to markets to bring about structural change and sustainability.

\subsubsection{Domestic investment}

Using the Solow model as a predictor, the investment ratio is a key determinant of economic growth regardless of a country's level of development (Solow, 1956). Investment ratio depends on the saving ratio. The neoclassical growth models of Solow (1956) and Swan (1956) also predict that an exogenously higher value of I/Y raises the steady-state level of output per effective worker as well as the growth rate. Thus, domestic capital is expected to influence economic growth significantly.

\subsubsection{Human capital}

Endogenous growth theory considers human capital as the major determinant of economic growth. In fact, it is the role of human capital that prevents the marginal product of capital from falling and thereby countries get richer (Lucas, 1988). However, right up until the second half of the 1990s, the role of human capital was linked to education, although a few authors had already recognized the importance of other factors such as health. Mankiw, Romer and Weil (1992) first considered not only education but also health in a broader analysis of human capital. Human capital in this study refers to both education and health.

\section{(a) Education}

Human capital, particularly that attained through education, has been emphasized as a critical determinant of economic progress (Barro \& Lee, 2001); and growth rates are affected by ideas and invention, which in turn are related to the stock of human capital, either through research and development activities or through the absorptive capacity of technology. According to Habiyaremye and Ziesemer (2006), there are three different views that explain how education affects the production process and contributes to economic performance. Firstly, education has the effect of increasing labor efficiency. Secondly, educated workers are able to perform complex tasks and are therefore not substitutable by unskilled workers. Thirdly, the education and skills of workers generate more output. Applied to the case of developing countries, these views suggest that educated workers help the country to absorb, implement and diffuse foreign technology, and stimulate economic growth.

(b) Health

Health, as a form of human capital, should be envisaged as a property that may be improved through investment in resources. Barro and Sala-i-Martin (2004) examined the relationship between economic growth and health and confirmed that good health is a crucial component of overall well-being. Similarly, Lopez-Casanovas (2005) argued that good health raises levels of human capital and has positive impacts on individual productivity and economic growth. As Sen (1988) points out, life expectancy implies an intrinsic capability on which personal welfare depends. Thus, the health variable is often captured by the life expectancy of individuals.

\subsubsection{Initial GDP per capita}

Barro and Lee (2001) have carried out an empirical analysis for a panel of around 100 countries from 1960 to 1990 and the findings strongly support the general notion of conditional 
convergence. The main implication from this study was, therefore, that poorer countries can achieve faster growth per capita provided that other variables remain constant.

\subsubsection{Population growth}

On the one hand, it is believed that population growth enlarges the labour force and, therefore has a positive impact on economic growth. A large population also provides a large domestic demand for goods and services provided that it has purchasing power. On the other hand, a large population growth is not only associated with food problems but also imposes constraints on the development of savings, foreign exchange and human resources. Thus, the net relationship between a greater population and economic growth depends on whether the return to human capital and expansion of knowledge is greater than the diminishing returns of natural resources. Thus, the effect of population growth on economic growth is ambiguous (Barro, 1997).

\subsubsection{Exchange rate}

In theory, the depreciation of the local currency exchange rate against the US dollar should represent a window of opportunity to boost exports. Thus it has been hypothesized that a depreciating and stable exchange rate is positively linked to economic growth.

\subsubsection{Inflation}

A high rate of inflation increases the uncertainty of business and hence is harmful to economic growth. It raises the cost of capital and inhibits capital investment. Andersen and Gruen (1995) and Fischer (1993) find that, on average, a one-percentage-point rise in the rate of inflation can cost an economy more than one-tenth of a percentage point in its growth rate. Indeed, Fischer? (1993) regards the inflation rate as the best single indicator of macroeconomic policies that may indicate the overall ability of the government to manage the economy. Hence, it can be hypothesized that a low and stable inflation rate promotes economic growth and efficiency in the long run.

\subsubsection{Openness}

Endogenous growth models predict that the openness of an economy could positively influence economic growth, because the flow of goods and investment across borders through international trade could be an effective means of diffusion of technology at the international level. Overall, the openness to trade can play an important role in raising the long-term sustainable rate of productivity growth (Dobre, 2008).

\subsubsection{Quality of infrastructure}

A study by Canning and Bennathan (2000) indicates that infrastructure, particularly telecommunications infrastructure, significantly increases economic growth. Thus, infrastructure is expected to contribute strongly to economic growth.

\subsubsection{Economic freedom}

The economic freedom variable aims to capture the freedom to choose and supply resources, completion in business, and the right to secure the property rights of individuals. As a result, economic freedom in a country is expected to promote economic growth via stimulating capital accumulation.

\subsubsection{Natural resources}

The effect of natural resources such as oil, ores and arable land on economic growth is also a debatable issue. However, there is an increasing consensus that this depends on how it is managed. If natural resources and their revenue are carefully managed, it would be a blessing; if not, however, it would be a curse. Thus, the effect of natural resources on economic growth is ambiguous. 


\subsubsection{Lack of access to the sea}

Almost one-third (or fifteen) of Africa's 53 countries are landlocked and have no access to the sea. The prevailing view is that being landlocked causes a disadvantage in economic development. Collier (2003) argues that a landlocked status is one of the four key factors preventing the poorest countries from growing and reaping the benefits of globalization. However, in recent years there has been an accelerated economic growth in many land-locked African countries including Ethiopia, Uganda, Rwanda and Zambia. Thus, the dichotomous dummy variable that captures lack of access to the sea is expected to have an ambiguous effect on economic growth. Based on the theoretical explanations discussed above, the independent variables and their expected relationships with economic growth are summarized in Table 2.

Table 2

Explanatory variables of economic growth, expected signs and data sources

\begin{tabular}{|l|c|l|l|}
\hline \multicolumn{1}{|c|}{ Variable } & + l- & \multicolumn{1}{c|}{ Data sources } \\
\hline Initial GDP/C & - & World Development Index (WDI) \\
\hline Foreign aid & + & World Development Index (WDI) \\
\hline FDI inflow & + & World Development Index (WDI) \\
\hline GFCF/GDP & + & World Development Index (WDI) \\
\hline Oil exports (\% of total exports) & + & http://www.geodatasource.com \\
\hline Ores and metal exports (\% of exports) & + & World Development Index (WDI) \\
\hline Arable land ratio & + & World Development Index (WDI) \\
\hline Population (in mill) & + & World Development Index (WDI) \\
\hline Degree of openness & + & World Development Index (WDI) \\
\hline Quality of infrastructure & + & World Development Index (WDI) \\
\hline Secondary school enrolment ratio & + & WDI database \\
\hline Life expectancy & + & WDI database \\
\hline Exchange rate & + & WDI database \\
\hline Inflation index & - & WDI database \\
\hline Economic freedom index & + & Heritage foundation index \\
\hline Land-locked (1=landlocked and 0=otherwise) & - & Various sources \\
\hline
\end{tabular}

\subsection{The trend of foreign aid and economic growth in Africa}

The diagrams below show the trends of foreign aid and economic growth in selected low income African countries such as Ethiopia, Tanzania, and Mozambique on the one hand; and Botswana and Morocco from the middle-income group on the other hand. Accordingly, Figures (1), (2) and (3) highlight a similar pattern of relationship between foreign aid and economic growth performance in Ethiopia, Tanzania, and Mozambique, respectively. On the other hand, we can find inconsistent patterns of relationship between foreign aid and economic growth in Botswana, and Morocco as shown in Figures (4) and (5) respectively. Thus, with this guiding information, it is important to investigate further the exact relationship between foreign aid and economic growth in Africa both at aggregate and disaggregated levels, based on the degree of economic development. 
Figure 1

The relationship between foreign aid and GDP growth in Ethiopia (low-income)

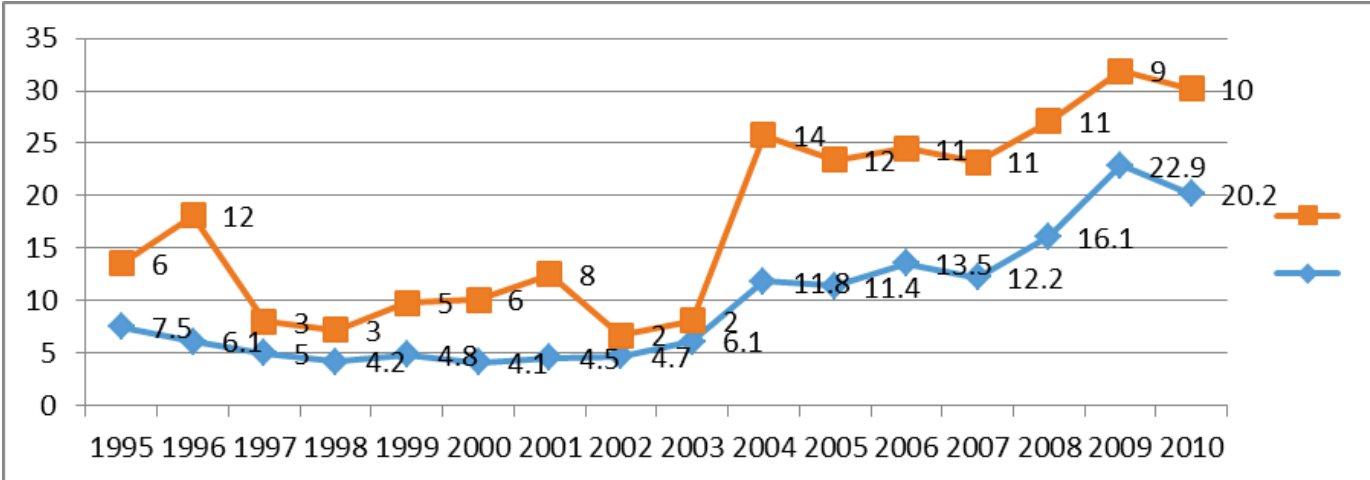

Figure 2

The relationship between foreign aid and GDP growth in Tanzania (low-income)

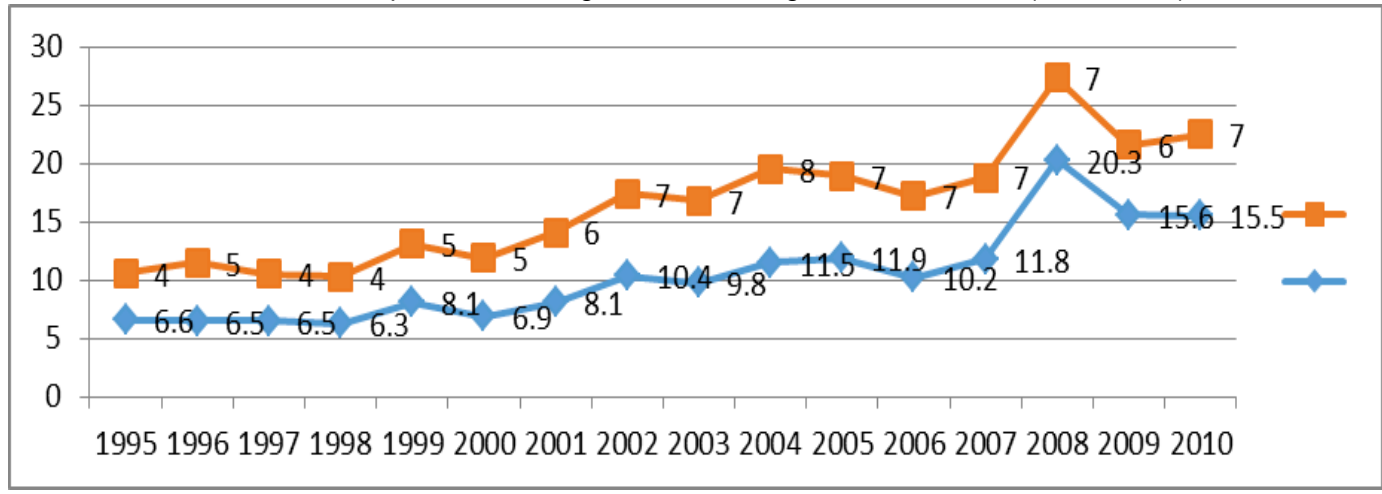

Figure 3

The relationship between foreign aid and GDP growth in Mozambique (low-income)

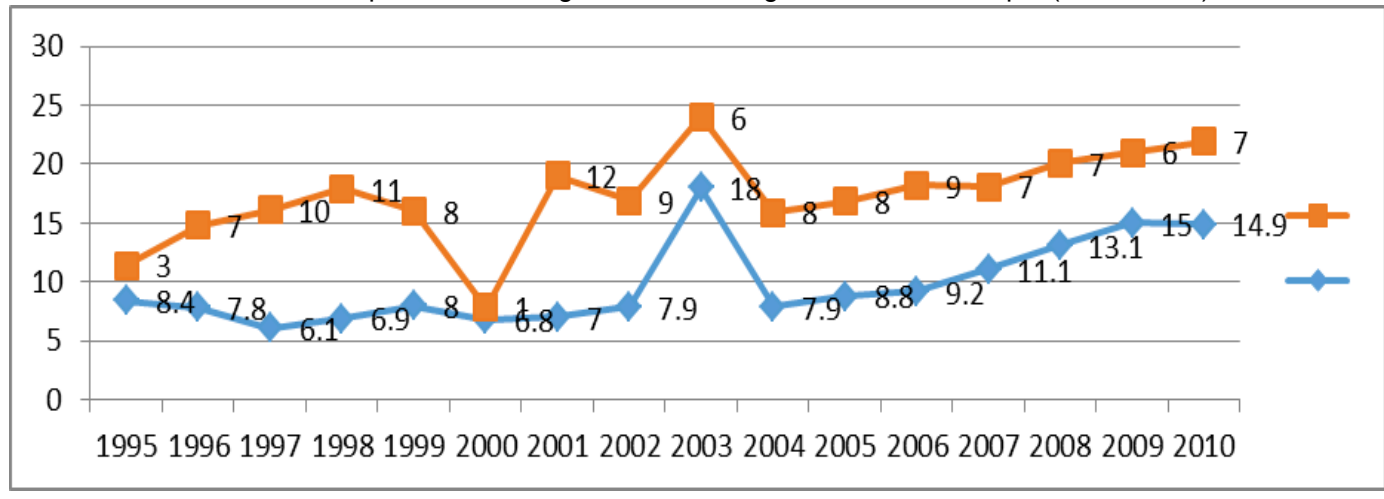


The relationship between foreign aid and GDP growth in Botswana (upper-middle-income)

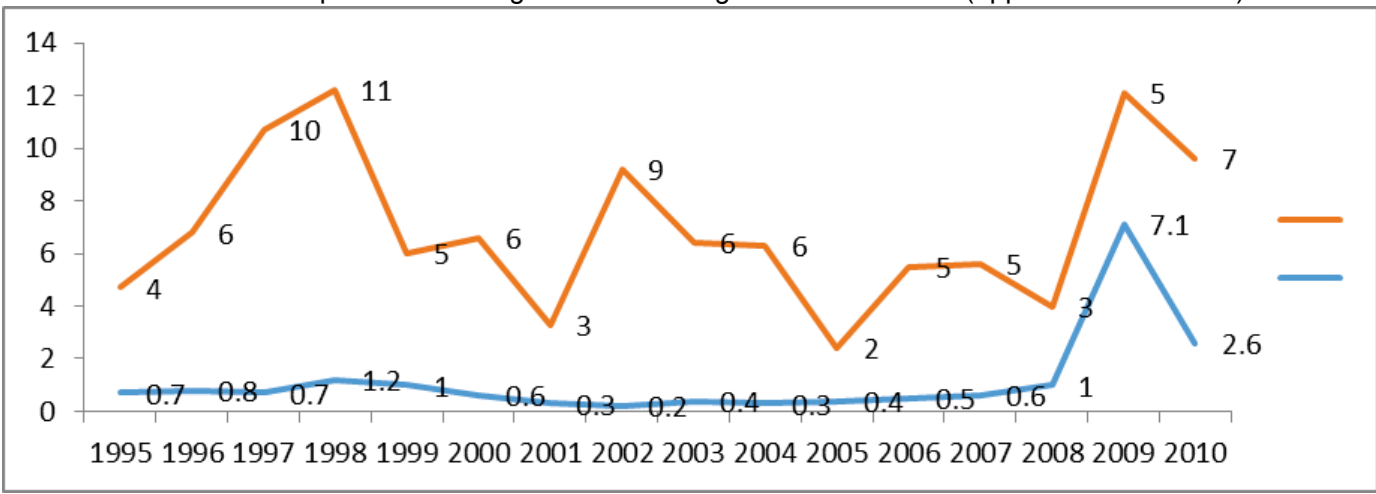

Figure 5

The relationship between foreign aid and GDP growth in Morocco (lower-middle-income)

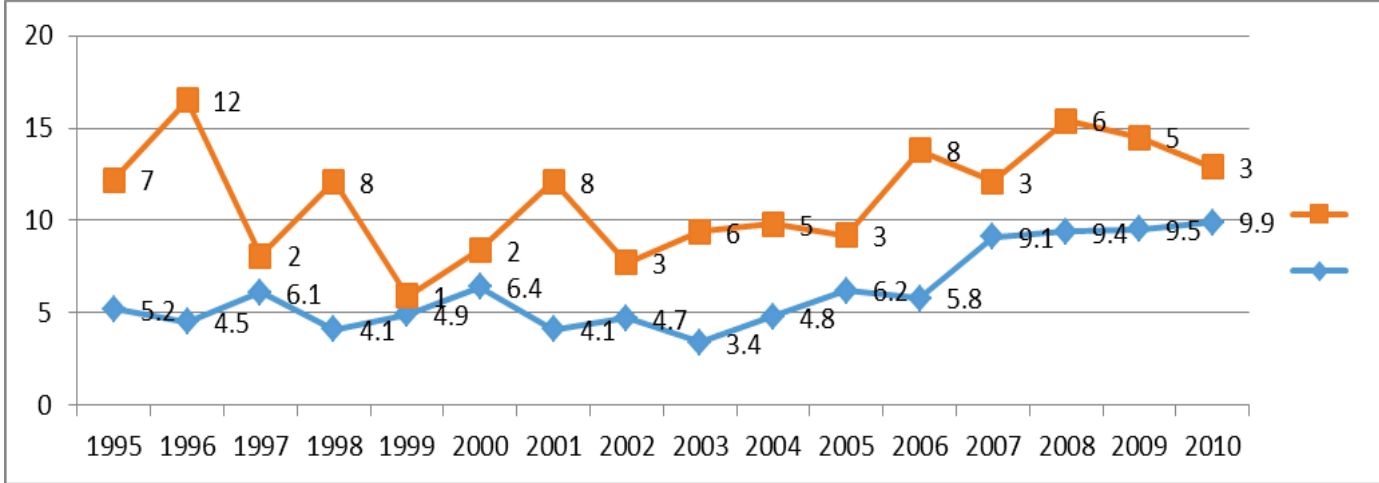

\subsection{The correlation between economic growth and independent variables}

Before we move on to the regression analysis, it is worth examining the correlations that exist between economic growth and foreign aid. In other words, the correlation coefficients of each variable determine the nature and strength of the relation between each factor and economic growth. Accordingly, correlation analysis not only helps to clarify relations among variables but also often suggests directions for experimental research such as regression analysis. Table 3 shows that there is a direct correlation between foreign aid and economic growth.

Similarly, the correlation analysis reveals that initial income per capita is negatively correlated with economic growth. On the other hand, the evidence shows that the ratio of GFCF/GDP, oil exports/total exports, degree of openness, life expectancy, and quality of infrastructure are positively correlated with economic growth in Africa.

\subsection{Regression results}

One of the most significant results from the full sample as well as the middle-income Africa subsample is initial GDP per capita (level of development of a given country at the beginning of 1995 ) is found to be a strong negative determinant of economic growth. More specifically, the coefficient of the initial $\mathrm{GDP} / \mathrm{C}$ variable was estimated at -0.001 , implying that convergence occurs at the rate of 0.1 per year. On the other hand, no significant evidence was found for lowincome African countries to converge at this point. However, though it was not significant, the negative sign of the coefficient suggests some indications of convergence in the region. 
Table 3

Partial correlation of economic growth with independent variables

\begin{tabular}{|l|c|c|}
\hline \multicolumn{1}{|c|}{ Variable } & Correlation & Significance \\
\hline Initial GDP/C & -0.1571 & $0.000^{\star * *}$ \\
\hline Foreign Aid & 0.0687 & $0.090^{*}$ \\
\hline FDI Inflow & 0.0361 & 0.390 \\
\hline GFCF/GDP & 0.3090 & $0.000^{* * *}$ \\
\hline Oil Exports (\% of total exports) & 0.1970 & $0.000^{* *}$ \\
\hline Ores and Metal Exports (\% of Exports) & 0.0115 & 0.78 \\
\hline Arable Land Ratio & 0.0362 & 0.389 \\
\hline Population (in mill) & 0.0357 & 0.396 \\
\hline Degree of Openness & 0.0762 & $0.069^{*}$ \\
\hline Quality of Infrastructure & 0.0859 & $0.040^{* *}$ \\
\hline Secondary School Enrolment Ratio & 0.0036 & 0.931 \\
\hline Life Expectancy & 0.0992 & $0.018^{\star *}$ \\
\hline Exchange Rate & 0.0010 & 0.981 \\
\hline Inflation Index (consumer price index) & -0.0514 & 0.221 \\
\hline Economic Freedom Index & -0.0016 & 0.970 \\
\hline Land-locked (0=landlocked and 1=otherwise) & 0.0551 & 0.189 \\
\hline
\end{tabular}

Our main variable of interest - aid per capita - has been found to be a statistically significant factor of economic growth for only low-income African countries, not for the middle-income African sub-sample. It is obvious that low-income African countries are heavily dependent upon foreign aid for supplementing their basic needs and even to support government budget. In these countries, most foreign aid amounts were not spent on areas related to economic growth. Moreover, some low-income African countries are effectively using foreign aid for education and health care, and these would enhance economic growth in the long term. On the other hand, the FDI variable has been found to be statistically significant at the five per cent level for the middleincome African sub-sample, but not for the low-income one. For instance, the result in Table 4 (column 3) implies that a one-per cent increase in FDI inflow would result in a 0.1 per cent increase in economic growth in middle-income African countries. Thus, whilst foreign aid has a strongly positive impact on economic growth in low-income African countries, it is the FDI inflow that has resulted in a significant impact on economic growth for middle-income African countries. The probable explanation is perhaps that low-income countries have few options of financial resources and this eventually enables them to create a better macro-economic management system and also to utilize foreign aid in a very efficient way. Donors also give smaller amounts of aid to middle-income African countries than to low-income ones.

Likewise, the empirical analysis indicates that a one- percentage increase in the ratio of fixed capital formation to total GDP will increase economic growth by 12.4 per cent and 12.4 per cent for middle-income and low-income African countries, respectively. Natural resource variables such as the ratio of oil exports to total exports were found to be statistically significant for only middle-income African countries but not for low-income ones. This is perhaps due to the fact that most of the middle-income African countries are currently oil exporters while many of the lowincome African countries are not.

On the other hand, no evidence was found for the minerals and ores variable to induce economic growth in a significant way in both sub-samples. Interestingly, however, the arable land ratio has been found to be a very important factor in stimulating economic growth mainly in lowincome African countries. This result is consistent with the current situation that low-income African countries, particularly those with ideal climates and arable land density, have recently achieved economic growth mainly driven by the high price in agricultural commodities. Accordingly, the result confirms that a one- per cent increase in the arable land ratio for lowincome African countries would increase economic growth approximately by 3.9 per cent. 
Table 4

System GMM estimation for the effect of foreign aid and other variables on economic growth

\begin{tabular}{|c|c|c|c|}
\hline Independent variables & Africa & Middle-Income Africa & Low-Income Africa \\
\hline Initial GDP/C & $\begin{array}{l}-.001^{* * *} \\
(.0002)\end{array}$ & $\begin{array}{l}-.001^{* \star \star} \\
(.0002)\end{array}$ & $\begin{array}{l}-.001 \\
(.001)\end{array}$ \\
\hline Foreign Aid & $\begin{array}{l}.0003 \\
(.0002)\end{array}$ & $\begin{array}{l}.0001 \\
(.0002)\end{array}$ & $\begin{array}{l}.002^{* * \star} \\
(.001)\end{array}$ \\
\hline FDI Inflow & $\begin{array}{l}.001^{* *} \\
(.0002)\end{array}$ & $\begin{array}{l}.001^{* *} \\
(.0002)\end{array}$ & $\begin{array}{c}.001 \\
(.0012)\end{array}$ \\
\hline GFCF/GDP & $\begin{array}{l}.144^{\star *} \\
(.063)\end{array}$ & $\begin{array}{l}.124^{*} \\
(.079)\end{array}$ & $\begin{array}{l}.124^{\star \star} \\
(.055)\end{array}$ \\
\hline Oil Exports (\% of total exports) & $\begin{array}{l}.131^{* \star *} \\
(.047)\end{array}$ & $\begin{array}{l}.127^{\star \star \star} \\
(.051)\end{array}$ & $\begin{array}{l}.112 \\
(.098)\end{array}$ \\
\hline Ores and Metal Exports (\% of Exports) & $\begin{array}{l}.008 \\
(.014)\end{array}$ & $\begin{array}{l}.003 \\
(.029)\end{array}$ & $\begin{array}{l}.007 \\
(.014)\end{array}$ \\
\hline Arable Land Ratio & $\begin{array}{l}.008 \\
(.019)\end{array}$ & $\begin{array}{l}.103 \\
(.066)\end{array}$ & $\begin{array}{l}.039^{* *} \\
(.021)\end{array}$ \\
\hline Population (in mill) & $\begin{array}{l}.028^{*} \\
(.015)\end{array}$ & $\begin{array}{l}.002 \\
(.019)\end{array}$ & $\begin{array}{l}.029 \\
(.025)\end{array}$ \\
\hline Degree of Openness & $\begin{array}{l}.042^{* *} \\
(.018)\end{array}$ & $\begin{array}{l}.075^{\star * \star} \\
(.026)\end{array}$ & $\begin{array}{l}.005 \\
(.016)\end{array}$ \\
\hline Quality of Infrastructure & $\begin{array}{l}.067 \\
(.107)\end{array}$ & $\begin{array}{l}.310^{*} \\
(.194)\end{array}$ & $\begin{array}{l}.435 \\
(.561)\end{array}$ \\
\hline Secondary School Enrolment Ratio & $\begin{array}{l}.028 \\
(.023)\end{array}$ & $\begin{array}{l}.115^{\star *} \\
(.049)\end{array}$ & $\begin{array}{l}.080^{* \star *} \\
(.028)\end{array}$ \\
\hline Life Expectancy & $\begin{array}{l}.099^{*} \\
(.056)\end{array}$ & $\begin{array}{l}.037 \\
(.081)\end{array}$ & $\begin{array}{l}.148^{*} \\
(.083)\end{array}$ \\
\hline Exchange Rate & $\begin{array}{l}-.0001 \\
(.0003)\end{array}$ & $\begin{array}{r}-.0004 \\
(.001)\end{array}$ & $\begin{array}{l}.0002 \\
(.0004)\end{array}$ \\
\hline Inflation Index (consumer price index) & $\begin{array}{c}-.001 \\
(.0013)\end{array}$ & $\begin{array}{l}-.001 \\
(.002)\end{array}$ & $\begin{array}{l}-.020^{\star \star *} \\
(.004)\end{array}$ \\
\hline Economic Freedom Index & $\begin{array}{l}.014 \\
(.045)\end{array}$ & $\begin{array}{l}-.024 \\
(.077)\end{array}$ & $\begin{array}{l}.075 \\
(.052)\end{array}$ \\
\hline $\begin{array}{l}\text { Access to the sea } \\
(0=\text { landlocked; } 1=\text { otherwise })\end{array}$ & $\begin{array}{l}1.407 \\
(.871)\end{array}$ & $\begin{array}{c}1.638 \\
(1.606)\end{array}$ & $\begin{array}{l}-.302 \\
(.728)\end{array}$ \\
\hline Constant & $\begin{array}{c}2.329 \\
(4.355)\end{array}$ & $\begin{array}{l}-3.407 \\
(8.102)\end{array}$ & $\begin{array}{c}6.217 \\
94.948)\end{array}$ \\
\hline P-value for Hansen Test & 0.36 & 0.27 & 0.18 \\
\hline Number of countries & 39 & 20 & 19 \\
\hline Observations per country & 15 & 15 & 15 \\
\hline Number of observations & 585 & 300 & 285 \\
\hline
\end{tabular}

Theoretically, the effects of population growth on economic growth are disputable. In line with this, no evidence has been found that population growth is a significant factor for growth in income per capita, both in middle-income and low-income countries.

The degree of openness of a country has been found to be an influential factor in economic growth in middle-income African countries but not in low-income ones. The empirical evidence shows that a one- per cent increase in trade openness would result in about a 7.5 per cent increase in economic growth for middle-income African countries. This implies that openness to trade can enhance productivity by enabling more efficient allocation of resources, by providing greater opportunities to exploit economies of scale and by exposing the domestic economy to greater competitive pressures. Moreover, infrastructure has been found to be a crucial factor in speeding up economic growth only in middle-income African countries, whereas no significant evidence was found in low-income African countries due to the fact that infrastructural development is still at the infant stage in such countries.

The education aspect of human capital has been captured by the level of secondary school enrolment ratio, while the health aspect of human capital is captured by life expectancy variable. 
Accordingly, it has been found that education is very critical both in middle-income and lowincome African countries in their efforts to induce sustainable and faster economic growth. By the same token, the life expectancy variable was found to be statistically significant at the ten per cent level, for the full sample as well as the low-income African sub-sample, implying that a healthy labour force is crucial for sustainable economic growth. On the other hand, no evidence was found that the exchange-rate variable significantly affected economic growth, both in the full sample as well as the sub-samples. This result is similar to other previous empirical studies which recorded mixed results for the role of exchange- rate policy on economic growth. Inflation has a mixed effect on economic growth both in the full sample as well as the sub-samples. For instance, inflation is negatively associated with and statistically significant only for the low-income African sub-sample; while it is statistically insignificant for middle-income African countries. Generally, a low, single-digit level of inflation does not seem to have a significantly negative effect on economic growth. However, a high level of inflation (as happened in Zimbabwe in 2008/2009) would damage the prospects of savings, investment and economic growth.

The economic freedom variable aimed to capture the freedom to choose and supply resources, completion in business, and the right to secure property rights of individuals. All these tend to motivate economic growth via stimulating capital accumulation. However, the empirical results found no evidence that economic freedom affected economic growth in Africa at this point. Lastly, the dummy variable that captured the state of being 'land-locked' was not statistically significant either.

\section{Conclusion}

The impact of foreign aid on economic growth is an ongoing issue for discussion. The impact of foreign aid was found to be closely related to the socio-economic environment and political situation of recipient countries. In order to find empirical analysis of the impact of aid on economic growth, this study attempted to use different variables related to economic output. It used data from major African countries by dividing them into low- income and middle- income countries according to the level of income per capita. The results revealed that the middle- income countries tended to experience a greater impact on their economic growth from FDI as well as from the revenue they generated from the export of natural resources (mainly oil exports); whereas the low- income countries were significantly affected mainly by foreign aid.

Thus this study shows that the criticism of foreign aid is flawed, at least in the case of lowincome African countries. In fact, foreign aid has played a critical role in stimulating economic growth through supplementing domestic sources of finance such as savings, and thus increasing the amount of investment and capital stock in low-income African countries.

\section{References}

ADDISON, T., MAVROTAS, G. \& M. McGILLIVRAY. 2005. Aid to Africa: An unfinished agenda. Journal of International Development, 17:989-1001.

ANDERSON, P. \& D. GRUEN.1995. Macroeconomic policies and growth. Published in Palle Andersen, Jacqueline Dwyer \& David Gruen. (eds.) Productivity and growth. Sydney: Reserve Bank of Australia: 279-319.

BARRO, R. 1997. Determinants of economic growth: A cross-country empirical study. Cambridge: MIT Press.

BARRO, R. \& J. Lee. 2001. International data on educational attainment: Updates and implications. Oxford Economic Papers, 53(3):541-563.

BARRO, R. \& X. SALA-i-MARTIN. 2004. Economic growth $\left(2^{\text {nd }}\right.$ ed.) Cambridge, Massachusetts: The MIT Press.

BOONE, P. 1996. Politics and the effectiveness of foreign aid. European Economic Review, 40(2):289-329. 
BURNSIDE, C. \& D. DOLLAR. 2000. Aid, policies, and growth. American Economic Review, 90(4): 847-868.

CANNING, D. \& E. BENNATHAN. 2000. The social rate of return to infrastructure investments. Policy Research Working Paper, no. 2390, Washington DC: The World Bank.

CHENERY, H. \& A. STROUT. 1996. Foreign assistance and economic development. American Economic Review, 56(4):6-19.

COLLIER, P. 2003. Primary commodity dependence and Africa's future. Published in B. PLESKOVIC \& N. STERM (eds.) Annual Proceedings of the World Bank Conference on Development Economics. York: Oxford University Press and World Bank.

DALGAARD, C., HANSEN, H. \& F. TARP. 2004. On the empirics of foreign aid and growth. Economic Journal, 114 (496):191-216.

DOBRE, C. 2008. The relation between openness to trade and economic growth. Central and Eastern European Online Library. Available at: www.ceeol.com [accessed 2013/09/24].

EASTERLY, W. 2003. Can foreign aid buy growth? Journal of Economic Perspectives, 17(3):23-48.

EKANAYAKE, E. \& CHATRNA, D. 2010. The effect of foreign aid on economic growth in developing countries. Journal of International Business and Cultural Studies, 3:140-155.

FISCHER, S. 1993. The role of macroeconomic factors in growth. Journal of Monetary Economics, 32(3):485-512.

GOMANEE, K., GIRMA, S. \& MORRISSEY, O. 2005. Aid and growth in Sub-Saharan Africa: Accounting for transmission mechanisms. Journal of International Development, 17(8):1055-1075.

GUPTA, K. \& ISLAM, M. 1983. Foreign capital, savings and growth: An international cross-section study. Dordrecht: Reidel Publishing Company.

HABIYAREMYE, A. \& ZIESEMER, T. 2006. Absorptive capacity and export diversification in subSaharan African countries. Maastrich: United Nations University.

HANSEN, H. \& TARP, F. 2000. Aid effectiveness disputed. Journal of International Development, 12: 375-398.

ISLAM, A. 1992. Foreign aid and economic growth: An empirical study of Bangladesh. Applied Economics, 24(5):541-544

JUSELIUS, K., FRAMROZE, M. \& TARP, F. 2011. The long-run impact of foreign aid in 36 African countries: Insights from multivariate time series analysis. Working Paper No. 2011/51, UNU-WIDER.

KOSACK, S. 2003. Effective aid: How democracy allows development aid to improve the quality of life, World Development, 31(1):1-22.

LOPEZ-CASANOVAS, G. 2005. Health and economic growth: Findings and policy implications. Cambridge, Massachusetts: The MIT Press.

LUCAS, R. 1988. On the mechanics of economic development. Journal of Monetary Economics, 22(1):3-42. MANKIW, N., ROMER, D. \& WEIL, D. 1992. A contribution to the empirics of economic Growth. Quarterly Journal of Economics, 107(2):407-437.

MBAKU, J. 2004. Institutions and development in Africa. N.J: Africa World Press, Inc.

McGILLIVRAY, M., FEENY, S., HERMES, N. \& LENSINK, R. 2006. Controversies over the impact of development aid: it works: It doesn't; it can, but that depends. Journal of International Development, 18(7):1031-1050.

MOREIRA, S. 2005. Evaluating the impact of foreign aid on economic growth: A cross-country study. Journal of Economic Development, 30(2):25-49.

MORRISSEY, O. 2001. Does aid increase growth? Progress in Development Studies, 1(1):37-50.

MOSLEY, P. 1980. Aid, savings and growth revisited. Oxford Bulletin of Economics and Statistics, 42(2):79-95.

MOSLEY, P., HUDSON, J. \& HORRELL, S. 1987. Aid, the public sector and the market in less developed countries. Economic Journal, 97(387):616-641.

MOYO, D. 2009. Dead aid: Why aid is not working and how there is a better way for Africa. New York: Farrar, Straus, and Giroux. 
MUNEMO, J., BANDYOPADHYAY, S. \& BASISTHA, A. 2007. Foreign aid and export performance: A panel data analysis of developing countries. Working Paper 2007-023A, St. Louis: Federal Reserve Bank of St. Louis.

PALLAGE, S. \& ROBE, M. 2001. Foreign aid and the business cycle. Review of International Economics, 9(4):641-672.

REE, J. \& NILLESEN, A. 2009. Aiding violence or peace? The impact of foreign aid on the risk of civil conflict in sub-Saharan Africa. Journal of Development Economics, 88:301-313.

SEN, A. 1988. Mortality as an indicator of economic success and failure. Economic Journal, 108(446):1-25. SOLOW, R. 1956. A contribution to the theory of economic growth. Quarterly Journal of Economics, 70(1):65-94.

SWAN, T. 1956. Economic growth and capital accumulation. Economic Record, 32(63):334-361. 